\title{
Liberalization and FDI Performance: Evidence from ASEAN and SAFTA Member Countries
}

\author{
Muhammad Shariat Ullah • Kazuo Inaba
}

Received: 7 April 2014 / Revised: 16 October 2014 / Accepted: 20 October 2014 /

Published online: 06 November 2014

(C) 2014 Ullah and Inaba; licensee Springer. This is an Open Access article distributed under the terms of the Creative Commons Attribution License (http://creativecommons.org/licenses/by/4.0), which permits unrestricted use, distribution, and reproduction in any medium, provided the original work is properly credited.

\begin{abstract}
The developing and least developed countries in the South and Southeast Asia have emerged as dynamic hosts of foreign direct investment; and inbound FDI growth surpassed that of the developing world during the decade 2001-2010. Yet foreign investment continues to flow quite unevenly into individual countries in the region, although majority of the Asian countries do emphasize liberalization unilaterally, bilaterally under the bilateral investment treaty (BIT) and the bilateral trade agreement (BTA), and regionally under the regional trade agreement (RTA). Under such scenarios, this study empirically assesses FDI determinants with a specific focus on the FDI effects of BIT, BTA, and RTA as well as of factors pertaining to institutional quality. Gravity-type econometric results of unbalanced panel data uncover that BIT, BTA, and RTA promote FDI insignificantly. It appears that the role of bilateral instruments in stimulating the inflow of foreign capital diminishes if liberal FDI policies already exist in the host country. Under such circumstances, the quality of the host country's legal and regulatory environment exerts a profound influence on firms' investment decisions. Nonetheless, core gravity variables are found to be important determinants of FDI.
\end{abstract}

Keywords FDI $\cdot$ ASEAN $\cdot$ SAFTA $\cdot$ BITs $\cdot$ BTAs $\cdot$ Institutional quality

JEL Classification C33 $\cdot$ F21 $\cdot$ F23

\section{M.S. Ullah}

University of Dhaka, Dhaka, Bangladesh

e-mail: shariat@univdhaka.edu

K. Inaba (四)

Ritsumeikan University, Kusatsu, Shiga, Japan

e-mail: inabak@ec.ritsumei.ac.jp 


\section{Introduction}

South and Southeast Asian countries are integrated under two distinct regional trade blocs, namely the South Asian Association for Regional Cooperation ${ }^{1}$ (SAFTA) and the Association of Southeast Asian Nations ${ }^{2}$ (ASEAN). Owing either to a perception of bolstering economic prosperity or to overcoming an economic crisis by injecting foreign capital and technology, developing and least developed participants ${ }^{3}$ of these trade blocs' undertook unilateral opening to international investments over recent decades. Consequently, FDI policies-i.e., national treatment, equity ceiling, sectoral opening, profit repatriation, and foreign exchange control—were gradually softened. Nonetheless, ASEAN and SAFTA members have maneuvered a wide range of fiscal incentives so as to remain more competitive and to feature attractive investment locations. Alongside the unilateral opening to FDI, these economies have signed an extensive number of bilateral investment treaties (BITs) over time. ${ }^{4}$ In addition, some countries have attempted to complement the investment liberalization process by forming bilateral trade agreements (BTAs); these are like free trade agreements (FTAs) that also contain provisions for stimulating investment at a bilateral level.

In the wake of the speedy liberalization of restrictions on FDI, coupled with a rising trend in the dislocation of operations by multinational enterprises (MNEs) to access locational advantages, South and Southeast Asia emerged as key destinations for inbound FDI. The Asian Development Bank (2007) reported that the liberalization of investment barriers by developing countries in Asia resulted in an upward trend of FDI flow into the region in recent years. Furthermore, the FDI flows to South and Southeast Asia exceeded FDI growth in developing countries in other regions (UNCTAD 2010). Although the developing and LDC members of ASEAN and SAFTA actively invite FDI by formulating investment-friendly policies, by offering incentives as a way to deliver higher competitiveness to the foreign firms, and by

\footnotetext{
${ }^{1}$ Regional cooperation in South Asia began with the formation of the South Asian Association for Regional Cooperation (SAARC) in 1985 by seven South Asian countries. Subsequently, the SAARC members signed the South Asian Preferential Trade Arrangement (SAPTA) in 1993 and transformed the SAPTA into the South Asian Free Trade Agreement (SAFTA) in 2004. Some of the SAARC members also belong to the Asia Pacific Trade Agreement (APTA). See Ullah and Inaba (2012) for details on the regionalization of South Asian countries.

${ }^{2}$ Member states of ASEAN have instituted far-reaching liberalization to facilitate and coordinate investment liberalization within the region since the late 1990s. In particular, the creation of the ASEAN Investment Area (AIA) in 1998 was a milestone initiative in the area of regional cooperation through investment liberalization. Plummer and Cheong (2009) provide a comprehensive literature on liberalization initiatives under the ASEAN.

${ }^{3}$ By referring to developing and least-developed participants of ASEAN and SAFTA, this research indicates nine countries, i.e., Bangladesh, Cambodia, India, Indonesia, Myanmar, Pakistan, the Philippines, Thailand, and Vietnam. This study selects these nine sample countries because it aims to unveil the determinants of FDI from the perspective of receiving countries that stand at a similar stage of economic development, offer comparable degree of liberalization but exhibit noticeable variation in hosting FDI. Countries like Singapore and Malaysia simultaneously receive and undertake FDI and therefore have been excluded from the analysis. In addition, some countries like Sri Lanka and Laos could not be included in the sampling frame because of non-availability of data.

${ }^{4}$ The total number of BITs implemented by the nine sample countries increased remarkably from 24 to 281 between 1990 and 2011.
} 
entering into a growing number of BITs, the performance in FDI attraction differs substantially among them. Hence, the critical question is what factors govern MNEs' decisions in choosing locations for investment.

Analyzing the FDI data of eight Asian countries-Hong Kong, Taiwan, Republic of Korea, Singapore, Malaysia, the Philippines, Indonesia, and ThailandChantasasawat et al. (2010) report that openness and corporate taxes are the driving forces of inward FDI in the East and Southeast Asian host countries. Their results further indicate that institutional characteristics-i.e., corruption, government stability, and rule of law-have no significant influence on FDI. Plummer and Cheong (2009) investigate ASEAN integration and its effects on FDI. Their findings demonstrate that BITs have insignificant positive effects on FDI inflow to the ASEAN countries. Vogiatzoglou (2007) unveil that the volume of bilateral trade between host and home countries, bilateral vertical production specialization links between them, international integration, degree of openness, growth rates, labor cost, and macroeconomic instability in the host country are the main determinants of FDI inflows from the selected OECD countries to the nine East Asian host countries (i.e., China, Hong Kong, Indonesia, Korea, Malaysia, the Philippines, Singapore, Taiwan, and Thailand).

While some studies addressed many aspects of FDI determinants, the role of investment treaties has been inadequately explored. Therefore, the present research attempts to examine FDI effects of BITs in the nine Asian countries in which a growing momentum in signing BITs has been prevalent. Apart from that, we discern the impact of bilateral investment agreements (BTAs) on firms' choices for investment locations. Developing and LDC member states of ASEAN and SFTA primarily attract vertical FDI, in which the investing firms tend to export the output from the host country. In this case, FDI and trade act as complements to one another. Owning to a complementary relationship between vertical investment and trade (Gast and Herrmann 2008), BTAs are likely to constitute an integral determinant of inward FDI. In particular, BTAs between the Southern and Northern countries can stimulate FDI from the latter to the former.

Furthermore, we assess the role of institutional quality in attracting inward FDI by examining law and order as well as corruption and internal conflict. Effects of these factors in the context of ASEAN and SAFTA countries have rarely been addressed in past studies. Because the sample hosts have already implemented an open-door policy toward foreign investment and they have maneuvered competitive incentive packages, institutional development might act as the driving force of future FDI inflows. Therefore, we aim to contribute by ascertaining the required institutional reforms to benefit from investment-friendly policies and incentives. The rest of the paper is structured as follows. Section 2 compares FDI policies and performance of the sample countries. Section 3 presents literature on FDI determinants. Section 4 outlines the econometric model and analyzes the empirical results. Finally, Sect. 5 gives the conclusion.

\section{FDI Policy and Performance}

\subsection{Evolution of Investment Policies}

FDI policies in the developing and LDC countries of SAFTA and ASEAN have undergone far-reaching changes in recent decades. These capital-deficient countries still 
strive for FDI by lowering barriers to capital inflows. Nonetheless, countries competing for inward FDI also grant fiscal stimuli to allure foreign investors, which has resulted in a "proliferation of incentives" (OECD 2004). In order to keep pace with the changing business environment and global business rules, FDI-seeking countries amend their investment statutes quite frequently. Alongside the current investment provisions, Tables 1 and 2 exhibit a brief summary of FDI policy evolution in selected countries. ${ }^{5}$ It is evident that investment liberalization at the country level began at different points of time and at varying degrees. Overall, the phase of liberalization in Southeast Asia preceded that of South Asia. In particular, three Southeast Asian countries-Indonesia, Thailand, and the Philippines-relaxed some of their regulations on FDI in the 1960s and 1970s. Thailand pioneered the introduction of the tax holiday in 1960, followed by Indonesia in 1967.6 Indonesia moved first in some areas including eliminating the ceiling on foreign equity holding, granting national treatment, guaranteeing against expropriation, and allowing concessional duty on import. By the 1970s, Thailand and the Philippines also instituted liberal FDI policies, similar to Indonesia. Vietnam joined the club of liberal economies in the late 1980s and adopted a liberal FDI policy regime by the early 1990s.

In South Asia, the liberalization of FDI policies commenced prior to the implementation of broad-based economic reforms. In particular, Bangladesh and Pakistan opened the door to foreign investors in the early 1980s, although these countries have changed their direction from import substitution to an export-led growth strategy since the early 1990s. India was relatively restrictive to FDI until the beginning of the 1990s. Although India opened the first export processing zone (EPZ) in Asia in 1965 , the FDI policy of the country at that time was highly restrictive, and industrialization was controlled by protected domestic sectors with a focus on import substitution strategy.

Although the initial journey of softening FDI policies in South and Southeast Asia ranged from the 1960s to the 1990s, investment policies gradually converged, and the current state of the policies and incentives mostly demonstrates similar attributes. ${ }^{7}$ Table 2 shows that SAFTA and ASEAN countries compete head to head in relation to offering generalized investment incentives and concessions. In some cases, even, smaller countries, like Bangladesh and Vietnam, offer more a liberal atmosphere than the bigger markets.

\subsection{FDI Trends in ASEAN and SAFTA Countries}

Table 3 compares the growth trends of inward FDI in developing countries across the globe, in the Asian countries as a whole, and in the nine sample countries that belong to either ASEAN or SAFTA. It is evident that during the 1990s, the aggregate growth of FDI in the nine selected hosts in Asia lagged behind FDI growth in the developing

\footnotetext{
${ }^{5}$ The FDI policy of Cambodia and Myanmar could not be compared due to data limitation.

${ }^{6}$ Indonesia revoked tax holiday on FDI from the year 1984 under the Law Number 7 passed in 1983. Since then, the government usually grants some tax concessions that ease tax burden of investors.

${ }^{7}$ In addition to the policies and incentives summarized in Table 2, every country designs some sectorspecific policies and incentive packages.
} 


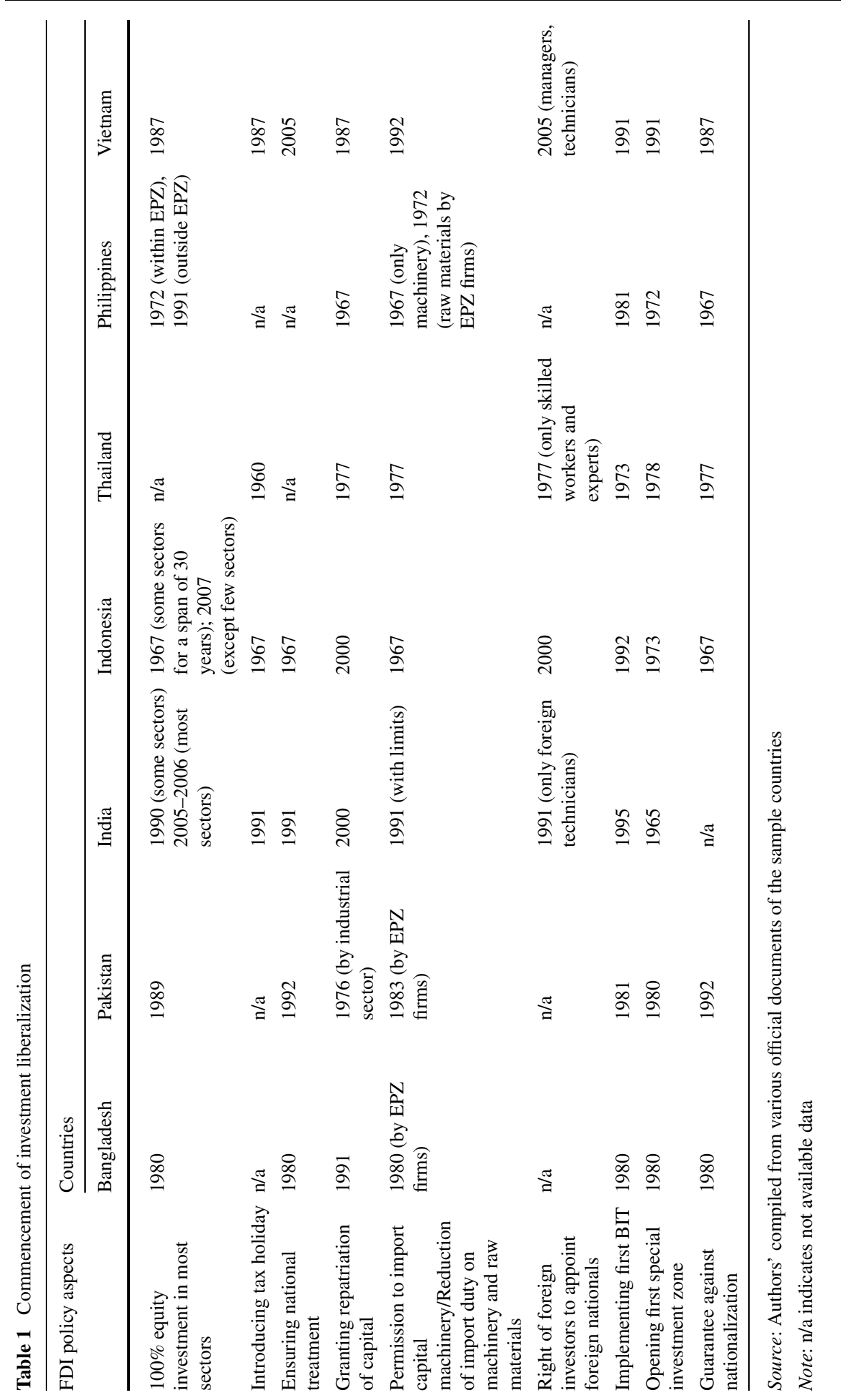




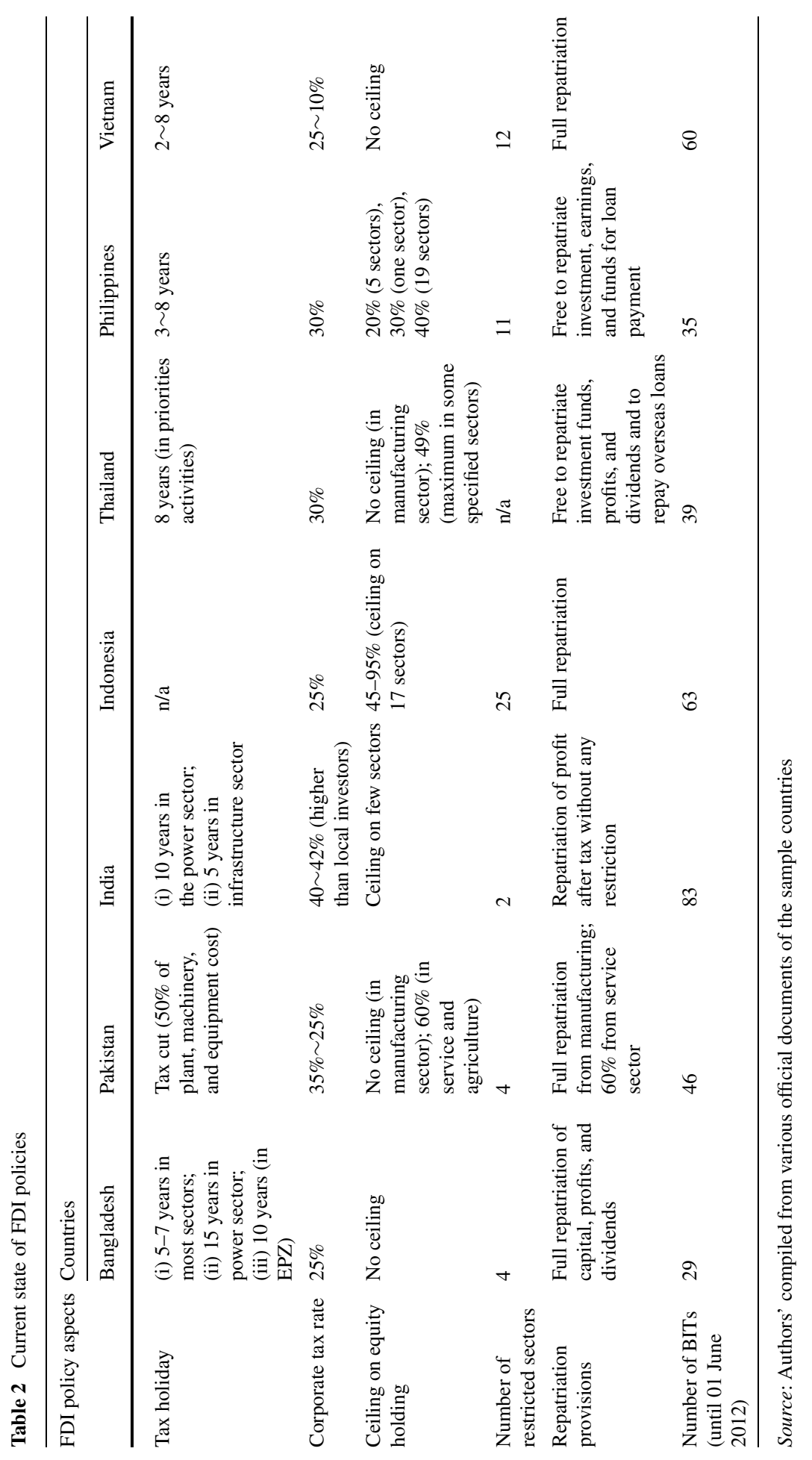


Table 3 Comparison of net inward FDI growth (period average)

\begin{tabular}{|c|c|c|c|c|}
\hline \multirow[t]{2}{*}{ Regions } & \multicolumn{4}{|l|}{ Period } \\
\hline & 1991-1995 & 1996-2000 & $2001-2005$ & 2006-2010 \\
\hline Developing World & 27.8 & 17.9 & 8.6 & 13.5 \\
\hline South, East, and Southeast Asia & 31.4 & 14.2 & 6.1 & 13.0 \\
\hline 9 sample countries of ASEAN/SAFTA & 20.7 & -7.8 & 36.8 & 16.3 \\
\hline
\end{tabular}

Source: Authors' calculations from the UNCTAD's data

Table 4 Inward FDI as \% of total inflows in nine countries (period average)

\begin{tabular}{|c|c|c|c|c|}
\hline \multirow[t]{2}{*}{ Host country } & \multicolumn{4}{|l|}{ Period } \\
\hline & 1991-1995 & 1996-2000 & 2001-2005 & 2006-2010 \\
\hline Bangladesh & 0.2 & 3.8 & 2.8 & 1.4 \\
\hline Cambodia & 0.8 & 1.6 & 1.0 & 1.1 \\
\hline India & 8.1 & 24.5 & 37.3 & 48.4 \\
\hline Indonesia & 28.9 & -3.1 & 1.2 & 13.0 \\
\hline Myanmar & 2.5 & 3.7 & 1.6 & 1.1 \\
\hline Pakistan & 5.8 & 3.8 & 5.5 & 6.5 \\
\hline Philippines & 13.9 & 14.1 & 5.4 & 3.9 \\
\hline Thailand & 26.3 & 37.9 & 35.0 & 13.7 \\
\hline Vietnam & 12.6 & 13.6 & 9.7 & 11.1 \\
\hline
\end{tabular}

Source: Authors' calculations based on the UNCTAD's data set

world as well as the growth achieved by the entire Asian region. In particular, the sample countries suffered from a negative flow during the last half of the 1990s, which was primarily due to the Asian financial crisis. The negative growth of FDI during the second half of the 1990s was greatly related to the substantial outflow of FDI from Indonesia. However, FDI growth of those economies during the first decade of the present century surpassed the growth achieved by the developing world and also by the developing Asian region. In particular, during the period 2001-2005, SAFTA and ASEAN countries witnessed spectacular growth in hosting FDI. Although the rate of FDI growth in these developing countries declined from 36.8\% during 2001-2005 to $16.3 \%$ between 2006-2010, their achievement was better than that of developing world and of South, East, and Southeast Asia.

\subsection{Relative Share in Regional FDI Inflows}

Even though developing Asia witnessed an FDI boom over the past decade, few countries hosted the lion's share. Table 4 presents country-specific FDI share during 19912010.

The salient features of FDI share can be summarized as follows: (1) India's share of inward FDI in Asia consistently rose at a remarkable rate, while that of the Philip- 
pines shrank constantly; (2) recent FDI inflows tended to be more concentrated on India, Indonesia, and Vietnam; (3) India, Indonesia, Pakistan, and Vietnam's share increased during 2006-2010 over the preceding period's share; (4) Bangladesh, Cambodia, and Myanmar accounted for a marginal share of the total regional FDI inflows; (5) Thailand hosted a dominant portion of total inward FDI until 2005, but its share substantially dropped during the subsequent period; (6) over time, the share of FDI for the Philippines worsened more than all of the remaining countries.

\section{Literature on FDI Determinants}

Empirical analyses of FDI determinants have been a key area of research for a long time. Since the 1990s, the rapid expansion of MNEs' operations has led to a substantial growth of FDI in the world that has outpaced the growth of world trade and output. For instance, during the period of 1990 to 2010, the average growth rate of inward FDI in the world was 13.2 percent, as compared to 8.1 and 2.6 percent average growth rates of world trade and output, respectively. ${ }^{8}$ A healthier growth rate of world FDI for decades has provided the impetus for exploring the reasons that firms undertake FDI. Research in this area is still advancing at a rapid rate, owing to the increased orientation of FDI from developed countries to developing ones that have heterogeneous characteristics. Some empirical studies focus on country case, while many others analyze FDI by pooling together developed countries (DCs) and less-developed countries (LDCs). Nonetheless, studies that aim to ascertain factors affecting FDI and its effect on specific economies are still in their infancy (Blonigen 2005). This is particularly true with respect to LDCs (Blonigen and Wang 2004).

Caves (1996) and Blonigen (2005) provide authoritative surveys of various strands of literature on FDI determinants. Besides, Chakrabarti (2001) presents a list of potential factors available in a vast array of cross-country studies on the determinants of FDI, and the research shows further examination of robustness of partial correlations between the level of inward FDI and a wide range of economic factors.

Overtime, the analytical focus of empirical models on the factors determining FDI has shifted from traditional determinants of locational advantages to policy-oriented issues, like exchange rate and openness as well as to the governance and human development areas and lately to liberalization under BITs, BTAs, and RTAs. Nevertheless, "the empirical literature on determinants of FDI is still young enough that most hypotheses are still up for grabs" (Blonigen 2005, p. 398). Essentially, there is scanty and variant evidence of the FDI effects of BITs, more so in the context of developing and LDC countries, although starting from the 1990s, the world witnessed a rapid proliferation of BITs. As such, the number of BITs in the world reached 2,756 as of May 2010, up from 385 at the end of the 1980s (UNCTAD 2000, 2010). ${ }^{9}$ Busse et al. (2010) and UNCTAD (2009) find that participation in BITs by developing economies

\footnotetext{
${ }^{8}$ Growth rates were calculated by the authors based on UNCTAD data for global FDI and trade and World Bank data for GDP.

${ }^{9}$ UNCTAD (2005) reported that $40 \%$ of the world's total BITs were signed between developed and developing countries, followed by $25 \%$ among developing countries and $13 \%$ between developed countries.
} 
positively influences investors' decisions in choosing alternative locations. A similar result was reported by Egger and Pfaffermayr (2004), who analyzed OECD data. Plummer and Cheong (2009) disclose that BITs signed by the ASEAN countries exert positive but insignificant effects on inward FDI, while the authors find a negative significant result for the entire sample of 34 home and 74 host countries. HallwardDriemeier (2003) finds little evidence that BITs have stimulated FDI flows from the OECD to developing countries. Mina (2012) suggests that FDI-seeking countries may attempt to sign BITs in tandem with improving their institutional functions. Thus, it is apparent that the literature lacks consensus on the association between FDI and BITs.

Furthermore, cross-country empirical studies on the FDI effects of BITs and of institutional characteristics are quite inadequate in the context of countries that are primarily FDI-receiving, instead of FDI-making. These countries exhibit comparable level of opening to foreign capital and have geographic proximity. Regardless of this, countries' performances in hosting FDI differ significantly. Blonigen and Wang (2004) argue that the factors determining the location of FDI vary systematically across LDCs and DCs in a way that is not captured by the current empirical models of FDI. Although some authors, including Chantasasawat et al. (2010), Plummer and Cheong (2009), and Vogiatzoglou (2007), have examined the determinants of FDI in East and Southeast Asian countries, these studies analyzed Asian host countries with dissimilar characteristics, such as major FDI-seeking countries (including Indonesia and Thailand) as well as major FDI-making countries (like the Republic of Korea, Malaysia, and Singapore). Nonetheless, SAFTA countries were not in the sample. Hence, the present study attempts to contribute to FDI research by exploring nine host economies located in the ASEAN and SAFTA regions that grant comparable policy environments and fiscal incentives under unilateral and bilateral liberalization schemes but demonstrate noticeable variation in hosting FDI. Furthermore, this research aims to deliver important policy implications for poor performers so as to increase inward FDI.

\section{Empirical Model and Econometric Results}

\subsection{Model Specification}

This study applies the well-known gravity model, which has been well proven as a robust empirical methodology to model international trade and investment. Tinbergen (1962) pioneered the use of the gravity model in the field of international trade. Since the inception of the gravity model in the 1960s, it has been widely applied in the fields of trade and factor mobility. Over time, it has appeared as the workhorse of ex-post methodology. Along with numerous applications of the gravity model in empirical studies of international economics, authors including Anderson (1979), Bergstrand (1985, 1989), Deardorff (1998), Evenett and Keller (2002), and Feenstra et al. (2001) have provided theoretical justification for the model. Recent empirics based on sound theoretical foundations have led to a richer and more accurate estimation and interpretation of the spatial relations described by the gravity model (Anderson 2011). 
Among others, Bellak et al. (2009), Bevan and Estrin (2004), Busse et al. (2010), Dee and Gali (2003), Gast and Herrmann (2008), Lee and Plummer (2004), Lesher and Miroudot (2006), Vogiatzoglou (2007), and Wei (2000) have applied the gravity model to investigate FDI determinants. In line with Newton's Law of Gravitation, the econometric model (1) outlines the core form of the gravity model of panel data

$$
\begin{aligned}
\ln \left(F D I_{i j t}\right)= & C+\beta_{1} \ln \left(G D P_{i t}\right)+\beta_{2} \ln \left(G D P_{j t}\right)+\beta_{3} \ln \left(G D P P C_{i t}\right) \\
& +\beta_{4} \ln \left(G D P P C_{j t}\right)+\beta_{5} \ln \left(D I S T_{i j}\right)+\varepsilon_{i j t} .
\end{aligned}
$$

In Eq. (1), In indicates natural logarithm; $i$ and $j$ stand for home and host country, respectively; and $t$ stands for the time period. In the panel data model, the inclusion of time dimension allows the intercept to change over time so as to account for cyclical influences on the explained variable. $\varepsilon_{i j t}$ stands for time varying composite error that consists of $\alpha_{i}+u_{i j t}$, where $\alpha_{i}$ denotes country-specific unobserved factors that affect the flows between $i$ and $j$, and $u_{i j t}$ represents white noise error.

The basic gravity model is usually augmented by incorporating other determinants that either facilitate or hinder FDI flows; such factors can be related to home country $(i)$, host country $(j)$, and country pairs $(i j)$. Thus, the extended gravity model takes the form of Eq. (2):

$$
\begin{aligned}
\ln \left(F D I_{i j t}\right)= & C+\beta_{1} \ln \left(G D P_{i t}\right)+\beta_{2} \ln \left(G D P_{j t}\right)+\beta_{3} \ln \left(G D P P C_{i t}\right) \\
& +\beta_{4} \ln \left(G D P P C_{j t}\right)+\beta_{5} \ln \left(D I S T_{i j}\right)+\gamma^{\prime}(Z)+\varepsilon_{i j t} .
\end{aligned}
$$

In Eq. (2), $Z$ represents a vector of other potential determinants of FDI. In the vector $Z$, two types of explanatory variables are to be included-i.e., variables that vary between host countries over time and the variables that vary between country pairs over time. As the potential determinants of FDI, the regression model of this study incorporates factors relating to market size, trade policy, human development, infrastructure, investment policy, and institutional quality. Altogether, this research includes nine additional variables to Eq. (1); Eq. (3) gives the final model for regression estimation:

$$
\begin{aligned}
\ln \left(F D I_{i j t}\right)= & C+\beta_{1} \ln \left(G D P_{i t}\right)+\beta_{2} \ln \left(G D P_{j t}\right)+\beta_{3} \ln \left(G D P P C_{i t}\right) \\
& +\beta_{4} \ln \left(\text { GDPPC }_{j t}\right)+\beta_{5} \ln \left(D I S T_{i j}\right)+\beta_{6}\left(H D_{j t}\right)+\beta_{7} \ln \left(\text { RAILPC }_{j t}\right) \\
& +\beta_{8} \ln \left(\text { OPEN }_{j t}\right)+\beta_{9}\left(\text { BTA }_{i j t}\right)+\beta_{10}\left(\text { BIT }_{i j t}\right)+\beta_{11}\left(A S E A N_{i j t}\right) \\
& +\beta_{12}\left(\text { ASEANJPN }_{i j t}\right)+\beta_{13}\left(\text { SAFTAJPN }_{i j t}\right)+\beta_{14}\left(\text { LAW }_{j t}\right) \\
& +\beta_{15}\left(\text { CORRUP }_{j t}\right)+\beta_{16}\left(\text { CONFLICT }_{j t}\right)+\varepsilon_{i j t} .
\end{aligned}
$$

The variables of Eq. (3) are defined below, while data sources are explained in the Appendix.

- $F D I_{i j t}$ : Annual inward FDI from country $i$ to country $j$ at year $t$.

- $G D P_{i t}$ : Real GDP of source country at year $t$.

- $G D P_{j t}$ : Real GDP of host country at year $t$.

- $G D P P C_{i t}$ : GDP per capita of home country at year $t$. 
- $G D P P C_{j t}$ : GDP per capita of host country at year $t$.

- $D I S T_{i j}$ : Geographic distance between source and receiving country.

- $H D_{j t}$ : Human development measured by secondary school enrollment rate of country $j$ at year $t$.

- $R A I L P C_{j t}$ : Rail line per 100,000 people of country $j$ at year $t$.

- $O P E N_{j t}$ : Openness of country $j$ at year $t$.

- $B T A_{i j t}$ : Bilateral trade agreement between country $i$ and $j$ at year $t$.

- $B I T_{i j t}$ : Bilateral investment treaty between country $i$ and $j$ at year $t$.

- $A S E A N_{i j t}$ : Dummy variable that accounts intra-ASEAN FDI.

- ASEANJPN ${ }_{i j t}$ : Dummy variable if Japan is the supplier of FDI to the ASEAN countries.

- SAFTAJPN ${ }_{i j t}$ : Dummy variable if Japan is the supplier of FDI to the SAFTA countries.

- $L A W_{j t}$ : Index of law and order of host country at year $t$.

- $C O R R U P_{j t}$ : Host country's index of corruption at year $t$.

- CONFLICT $T_{j t}$ : Index of internal conflict of country $j$ at year $t$.

The dependent variable is the annual flow of FDI in millions of current US dollars from country $i$ to country $j$ at time $t$. This research analyzes unbalanced panel data of annual inward FDI to the nine Asian host countries and from the 23 major source countries. The sample host countries include six participants (i.e., Cambodia, Indonesia, Myanmar, the Philippines, Thailand, and Vietnam) of ASEAN and three member states (Bangladesh, India, and Pakistan) of SAFTA. The data period covers 1995-2010.

Among the drivers of FDI, the most conventionally studied include GDP and GDP per capita, which indicate market size. Market-seeking FDI tends to flow in large markets represented by high income in the host country. Chakrabarti (2001) evidences that among the potential indicators of FDI, the role of market size/per capita GDP of a host country is the most substantial and robust. Similarly, a source country's income promotes FDI because rich countries make higher investments than poor ones. Thus, FDI is an increasing function of income variables.

Greater geographic distance between countries acts as a deterrent to FDI flow. Distance lowers the magnitude of investment not only because of the higher cost of investment but also owing to increased cultural dissimilarities between two distant countries than that of two proximate countries. Trade-related costs arising from greater geographic distance tend to exert more influence on MNCs that engage in vertical FDI. Based on Markusen's knowledge capital model (Markusen 2002), one of the key determinants of vertical FDI is lower trade costs. Under this consideration, the distance variable is expected to exhibit a negative sign.

The development of human capital in the host country is an important stimulus for FDI. Upon examining the role of the human capital level on FDI inflows in developing countries, Noorbakhsh et al. (2001) reveal that human capital of the host country is one of the most important forces of FDI attraction, and its importance has become greater over time. In a similar vein, Reiter and Steensma (2010) explain that FDI inflows in developing countries are strongly affected by improvement in the human development of the host country. Multinationals can improve their operational efficiency and strengthen their competiveness by investing in a country that possesses 
qualified manpower. The current study captures the level of human capital by the host country's secondary school enrollment ratio.

Infrastructure is considered to be a crucial factor to induce foreign investment. An increase in the host country's infrastructure endowment is capable of attracting more FDI (Bellak et al. 2009). The literature on FDI determinants suggests a wide variety of measures of infrastructure-i.e., road density, paved road density (Vogiatzoglou 2007), rail line density (Bellak et al. 2009), Internet users, telephone users (Chantasasawat, et al. 2010), and electricity consumption. In this research, we use the host country's rail line per capita as the measure of the infrastructure.

This research employs four indicators: trade openness, BIT, BTA, and RTA, all of which account for a country's extent of investment liberalization. Openness to international trade plays a complementary role to FDI inflow. Trade openness softens impediments to trade that ultimately facilitate the import of materials and machinery as well as export to foreign markets. Former studies have reported a positive relationship between openness and inward FDI. The concept of openness is very broad and can be measured by incorporating various policy aspects of the goods market, the service market, and the capital market. However, the simplest way to assess openness is to examine the measurement of trade as a percentage of GDP. Thus, the degree of openness in the host country is calculated in the following way:

$$
\operatorname{OPEN}_{j t}=\frac{\operatorname{EXPORT}_{j t}+\mathrm{IMPORT}_{j t}}{G D P_{j t}} .
$$

Bilateral investment treaties (BITs) and bilateral trade agreements (BTAs) are the prime avenues of investment liberalization at a bilateral level. BITs encourage foreign investment reciprocally by lowering barriers, ensuring protection, and granting incentives, while BTAs promote both trade and investment liberalization through the reduction of trade and investment regulations. In their efforts to attract and benefit from FDI, host countries attempt to liberalize and customize investment provisions by negotiating BITs and BTAs. Therefore, the growth of BITs and BTAs should be positively associated with inward FDI.

The integration of economies under regional trade agreements (RTAs) has been growing around the globe at an increasing pace, and more and more RTAs tend to incorporate provisions for facilitating intra-regional investment. Southeast Asian countries foster regional connectivity under ASEAN, while South Asian countries do so under SAARC. In order to explore the role of ASEAN integration on intra-regional investment flows, this research incorporates the ASEAN dummy variable. However, a similar dummy is not used for the SAFTA countries, particularly because this trade bloc hardly facilitates intra-regional investment. Furthermore, we investigate the extent of integration of Japan with ASEAN and SAFTA countries by incorporating two dummies. ${ }^{10}$ The underlying reason for using these dummy variables is that Japan is one of the major investing economies in the world, and we endeavor to examine whether the level of Japanese investment differs between South and Southeast Asia.

\footnotetext{
${ }^{10}$ In addition, the roles of China and South Korea have also been examined since these countries' significance is growing over time in both regions.
} 
A positive significant sign will substantiate that Japan and the sample host countries belonging to ASEAN and SAFTA are integrated via FDI, while a negative sign will nullify such intuition. Any divergence in the estimated results for the two sub-regional groups will underscore the necessity for heightening integration with Japan in order to host more Japanese multinationals.

Multinationals might respond to political and institutional changes when making their investment decisions (Plummer and Cheong 2009). FDI inflow and institutional quality are closely interlinked because high-quality institutions reduce political risk and ensure smooth operations. A higher degree of political risk is a threat and discourages foreign investment. In order to capture the role of institutional quality on inward foreign investment, this study takes into account three indices of a host country: the law and order index, the corruption index, and the index of internal conflict. A host country's law and order situation constitutes an integral part of its overall business environment. A strong and impartial legal system promotes an investment-friendly environment and heightens investors' confidence, while a weak law and order condition reflects institutional loopholes and high risk that eventually deters investment. In particular, a deteriorated law and order condition exerts a direct threat on property rights. Therefore, the index of law and order should be positively linked with the inflow of foreign capital. Another important dimension of political risk is the amount of corruption that exists in an economy. The intensity of corruption reduces FDI, as it increases the cost of doing business. ${ }^{11}$ The final variable of our empirical model is the host country's index of internal conflict, which highlights the degree of political violence in a country, such as terrorism, civil war, coup threat, and civil disorder. Persistent conflicts among political parties or between political parties and civilians frighten actual and potential investors, and this eventually has a profound negative effect on the future inflow of foreign investment.

\subsection{Methodological Aspects}

The panel data is suitable for random and fixed effects models, which are superior to ordinary least squares because unobserved heterogeneity can be accounted for. In a similar vein to Baldwin (1994), Bellak et al. (2009), and Cuyvers et al. (2011), this research applied the random effects model with the correction of auto-correlated errors (AR1) detected by the Wooldridge's (2002) test of serial correlation. Inward FDI may not be contemporaneously responsive to social, political, and economic changes. Therefore, following Bellak et al. (2009), Cuyvers et al. (2011), and Egger and Winner (2005), we used one-year-lagged values of the variables, which also helped to overcome the possibility of endogeneity. We checked the multicollinearity with the correlation matrix and variance inflation factor (VIF). The VIF score of $O P E N_{j t}$ was above the tolerance limit; ${ }^{12}$ hence, we dropped this variable in the final estimations. As a result, the mean of the VIF of the final model has substantially dropped and

\footnotetext{
${ }^{11}$ Contrary literature on the role of corruption also exists. For example, Egger and Winner (2005) find corruption as a stimulus for inward FDI to a large set of developed and less-developed countries.

${ }^{12} \mathrm{VIF}>10$ is an indication of high collinearity (Baum 2006). Estimates of VIF are not reported.
} 
was well below the threshold limit. In order to check the specification bias, we conducted RESET tests (Ramsey 1969) as described in Silva and Tenreyro (2006). The $p$ values of all estimates are insignificant at any level that rules out possibility of any misspecification.

In the dependent variable, there is missing data for some country pairs in certain years. The literature on the gravity model suggests that the simplest solution to missing or zero values in a dependent variable is to omit those observations and confine the estimation to the rest of the samples (in other words, to make a truncated estimation). Baldwin (1994) concluded that zero values do not have much impact on empirical results. The second alternative is to scale the dependent variable with a certain value, as done by Eichengreen and Irwin (1995). Moreover, some authors, including Rose (2004) and Soloaga and Winters (2001), have used the Tobit model (censored regression) in the presence of zero values in the data set. Following Eichengreen and Irwin (1995), we scaled the value of the dependent variable with one in the $\log$ transformation process.

Table 5 reports the correlation matrix of the explanatory variables. The pairwise highest correlations of 0.66 is detected between two measures of institutional quality-i.e., indices of internal conflict and law and order in the host country. This justifies the inherent association between a higher index of internal conflict (low intensity of conflict) and a higher index of law and order (better law and order). Considering this obvious fact, we regressed the institutional quality measures separately.

It appears from the descriptive statistics (see Table 6) that the variability is higher between country-pairs than within country-pairs for all variables, except the ones that pertain to the various dimensions of institutional quality. A slightly higher variability of institutional quality factors within a country-pair indicates relatively unstable and fluctuating strengths of institutions.

\subsection{Empirical Results}

Table 7 provides the empirical results of the model set forth in Eq. (3). The findings clearly establish the expected signs of the key gravity variables-i.e., income and distance. It appears that the FDI effects of host and home country GDPs are positive and significant. Nonetheless, the marginal effect of the host GDP exceeds that of the home GDP, which implies that growth of production capacity in host countries positively contributes to attract FDI. Higher per-capita income of the host country motivates the inflow of foreign investment, while that of the home country negatively affects firms' decisions to undertake FDI. In other words, a rise in GDP per capita in host countries motivates inward FDI due to an increase in the market's buying capacity. As usual, the geographic distance between home and host country is found to affect FDI flow at a negative significant rate.

In the extended models (see Regressions II-IX), host countries' human capital appears to exert a significant positive effect on the inflow of foreign capital, and this result is consistent with Noorbakhsh et al. (2001) and Reiter and Steensma (2010). Development of a railway network in the host country also has expected positive influence on the FDI decision of multinationals. The estimated coefficients of the rail line per capita remains significant even after implementing additional control variables. Thus, infrastructure constitutes a dominant determinant for hosting FDI. 


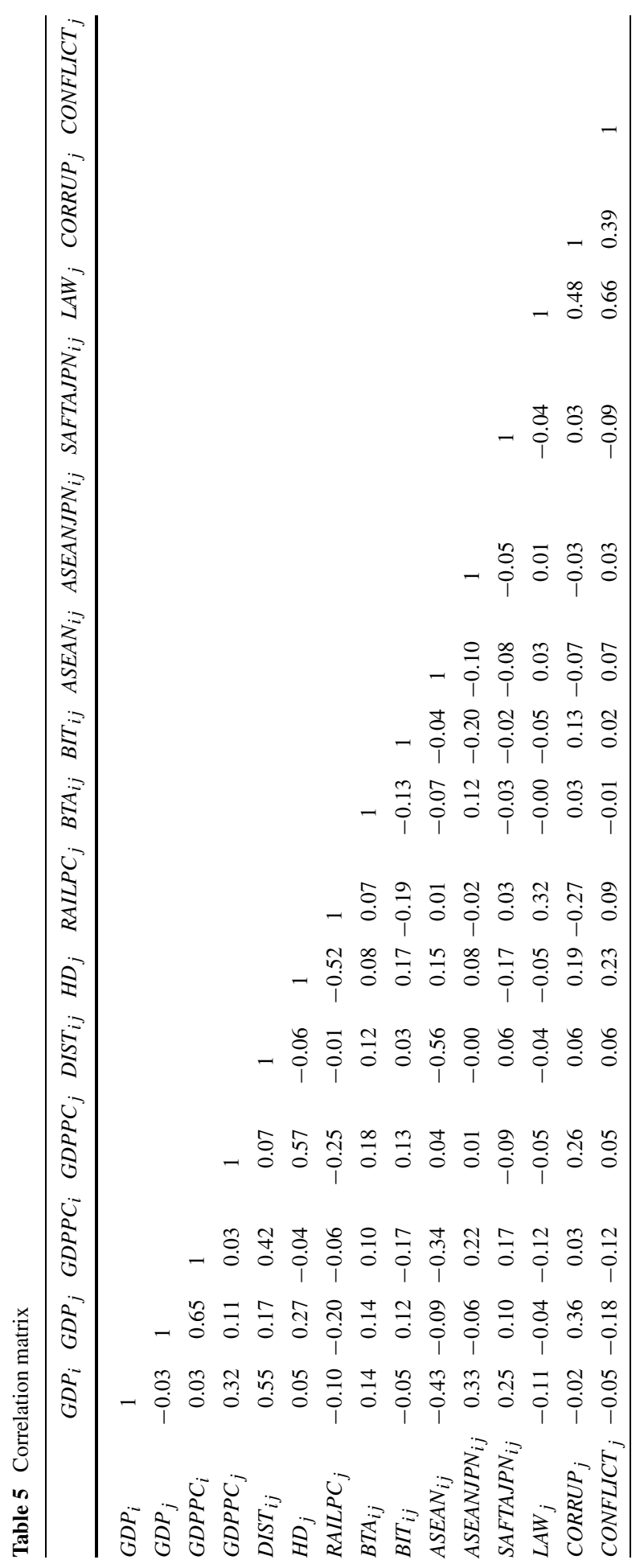


Table 6 Descriptive statistics

\begin{tabular}{|c|c|c|c|c|c|}
\hline Variable & & Mean & Std. dev. & Min. & Max. \\
\hline \multirow[t]{3}{*}{$\ln F D I_{i j}$} & Overall & 3.64 & 2.21 & -4.60 & 9.55 \\
\hline & Between & & 1.69 & -0.20 & 7.49 \\
\hline & Within & & 1.47 & -3.75 & 8.56 \\
\hline \multirow[t]{3}{*}{$\ln G D P_{i}$} & Overall & 27.08 & 1.60 & 21.96 & 30.09 \\
\hline & Between & & 1.59 & 22.31 & 29.95 \\
\hline & Within & & 0.19 & 26.41 & 27.82 \\
\hline \multirow[t]{3}{*}{$\ln G D P_{j}$} & Overall & 24.72 & 1.40 & 21.67 & 27.60 \\
\hline & Between & & 1.38 & 22.23 & 27.06 \\
\hline & Within & & 0.29 & 24.01 & 25.44 \\
\hline \multirow[t]{3}{*}{$\ln G D P P C_{i}$} & Overall & 9.62 & 1.06 & 5.73 & 10.64 \\
\hline & Between & & 1.05 & 6.16 & 10.55 \\
\hline & Within & & 0.15 & 9.01 & 10.32 \\
\hline \multirow[t]{3}{*}{$\ln G D P P C_{j}$} & Overall & 6.47 & 0.75 & 4.70 & 7.91 \\
\hline & Between & & 0.72 & 5.35 & 7.70 \\
\hline & Within & & 0.24 & 5.83 & 7.22 \\
\hline \multirow[t]{3}{*}{$\ln D I S T_{i j}$} & Overall & 8.33 & 0.82 & 6.28 & 9.70 \\
\hline & Between & & 0.82 & 6.28 & 9.70 \\
\hline & Within & & 0.00 & 8.33 & 8.33 \\
\hline \multirow[t]{3}{*}{$\ln H D_{j}$} & Overall & 3.93 & 0.39 & 2.77 & 4.44 \\
\hline & Between & & 0.36 & 3.36 & 4.38 \\
\hline & Within & & 0.18 & 3.35 & 4.41 \\
\hline \multirow[t]{3}{*}{$\ln R A I L P C_{j}$} & Overall & 1.26 & 0.83 & -0.67 & 2.40 \\
\hline & Between & & 0.83 & -0.52 & 2.34 \\
\hline & Within & & 0.07 & 1.11 & 1.54 \\
\hline \multirow[t]{3}{*}{$B T A_{i j}$} & Overall & 0.03 & 0.16 & 0.00 & 1.00 \\
\hline & Between & & 0.12 & 0.00 & 1.00 \\
\hline & Within & & 0.11 & -0.35 & 0.96 \\
\hline \multirow[t]{3}{*}{$B I T_{i j}$} & Overall & 0.46 & 0.50 & 0.00 & 1.00 \\
\hline & Between & & 0.44 & 0.00 & 1.00 \\
\hline & Within & & 0.25 & -0.47 & 1.40 \\
\hline \multirow[t]{3}{*}{$A S E A N_{i j}$} & Overall & 0.15 & 0.36 & 0.00 & 1.00 \\
\hline & Between & & 0.34 & 0.00 & 1.00 \\
\hline & Within & & 0.12 & -0.78 & 0.47 \\
\hline \multirow[t]{3}{*}{$\operatorname{ASEANJPN}_{i j}$} & Overall & 0.06 & 0.24 & 0.00 & 1.00 \\
\hline & Between & & 0.24 & 0.00 & 1.00 \\
\hline & Within & & 0.02 & 0.00 & 1.00 \\
\hline \multirow[t]{3}{*}{$\operatorname{SAFTAJPN}_{i j}$} & Overall & 0.03 & 0.17 & 0.00 & 1.00 \\
\hline & Between & & 0.17 & 0.00 & 1.00 \\
\hline & Within & & 0.00 & 0.03 & 0.03 \\
\hline
\end{tabular}


Table 6 (Continued)

\begin{tabular}{llllll}
\hline Variable & & Mean & Std. dev. & Min. & Max. \\
\hline $\ln L A W_{j}$ & Overall & 1.18 & 0.30 & 0.04 & 1.61 \\
& Between & & 0.19 & 0.80 & 1.47 \\
& Within & & 0.24 & 0.41 & 1.71 \\
$\ln$ CORRUP $_{j}$ & Overall & 0.66 & 0.36 & 0.00 & 1.39 \\
& Between & & 0.20 & 0.18 & 0.91 \\
& Within & & 0.30 & 0.05 & 1.40 \\
$\ln$ CONFLICT & Overall & 2.12 & 0.22 & 1.41 & 2.48 \\
& Between & & 0.14 & 1.95 & 2.38 \\
& Within & & 0.17 & 1.56 & 2.50 \\
\hline
\end{tabular}

This research indicates that investment liberalization by entering into BTAs and BITs fails to promote FDI in developing countries in Asia. Plummer and Cheong (2009) also report a similar result for the BITs of ASEAN countries. Although this research has produced the desired positive signs of the estimated coefficients of both variables, the results lack statistical significance at any level, even with two years of lag from the year of implementation. This finding discloses the fact that BTAs and BITs have no beneficial effect on firms' FDI initiative.

Like bilateral liberalization, integration under ASEAN promotes intra-ASEAN investment at an insignificant rate. Hence, ASEAN countries are yet to gain a worthy effect of creating AIA. Similarly, the investment relationship between Japan and ASEAN countries lacks statistical significance. On the contrary, the investment effect of Japan on SAFTA countries is negative and highly significant. This result reveals that SAFTA countries are less integrated with Japan than that ASEAN countries. As a result, countries in South Asia receive a significantly lower flow of FDI from Japan than that of countries in East Asia. Because Japan is a dominant source of FDI, SAFTA countries need to foster relations with Japan. ${ }^{13}$

Among the three indicators pertaining to institutional quality, the law and order situation has a profound impact on inward FDI. This result is consistent with the literature (Busse and Groizard 2008; Morrissey and Udomkerdmongkol 2012) and proves that the host countries possessing higher levels of institutional strength will benefit from the increased flow of FDI. In other words, countries with a vulnerable law and order situation are less likely to benefit from booming FDI in Asia. The extent of corruption in the FDI-receiving country shows no statistical implication, although the expected sign is evident. Chantasasawat et al. (2010) also report an insignificant effect of corruption on FDI inflow to Latin America, East and Southeast Asia, and China. Finally, empirical results show that a firm's decision to implement

\footnotetext{
${ }^{13}$ The estimated results with additional dummies for examining the role of China and Korea as a supplier of FDI to the ASEAN and SAFTA countries evidence that FDI linkage between ASEAN and China is positive significant while such relationship is absent in case of SAFTA. In fact, China does not appear at all as a supplier of FDI to the SAFTA countries. On the contrary, FDI effect of Korea is insignificant in the case of both ASEAN and SAFTA.
} 


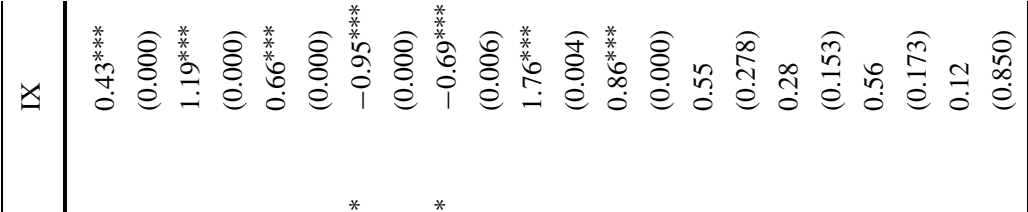

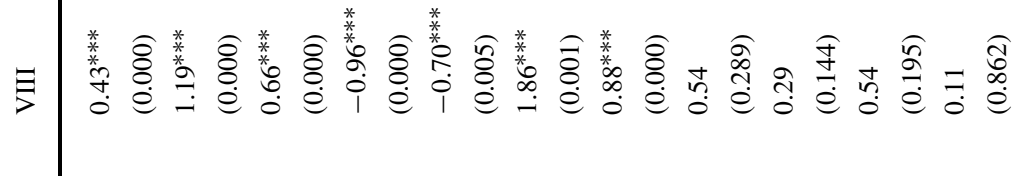

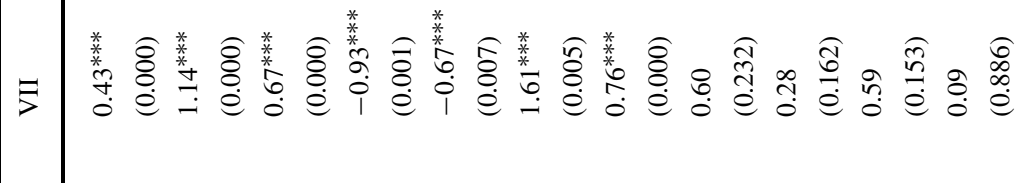

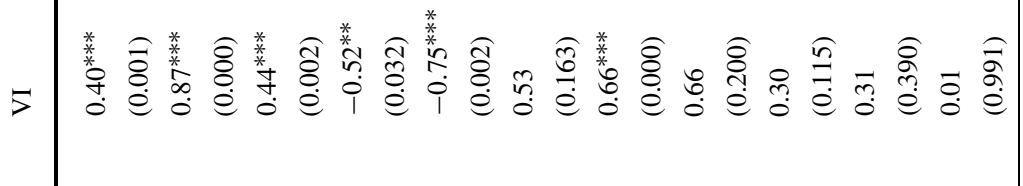

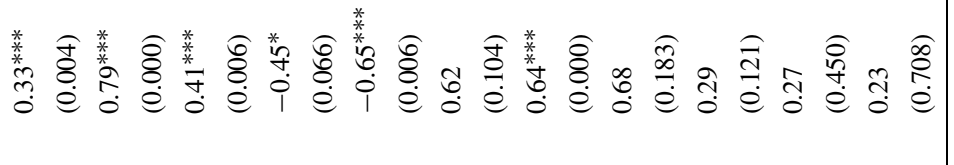

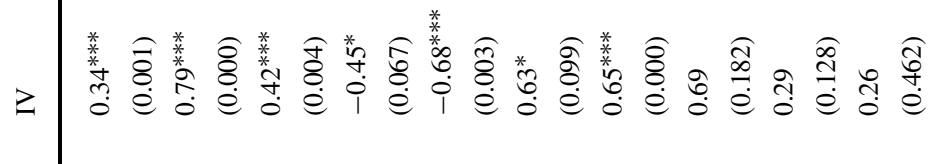

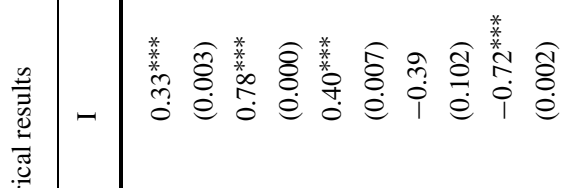

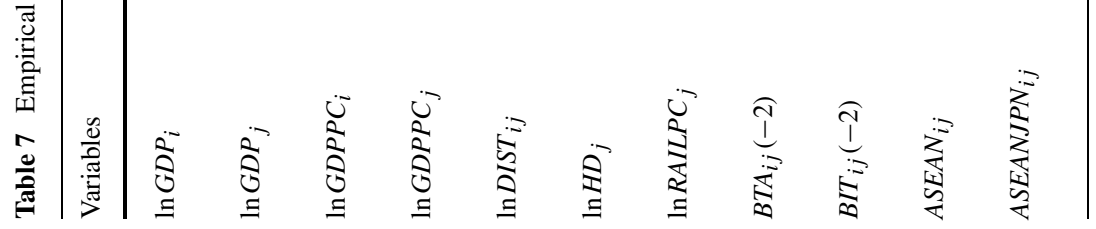




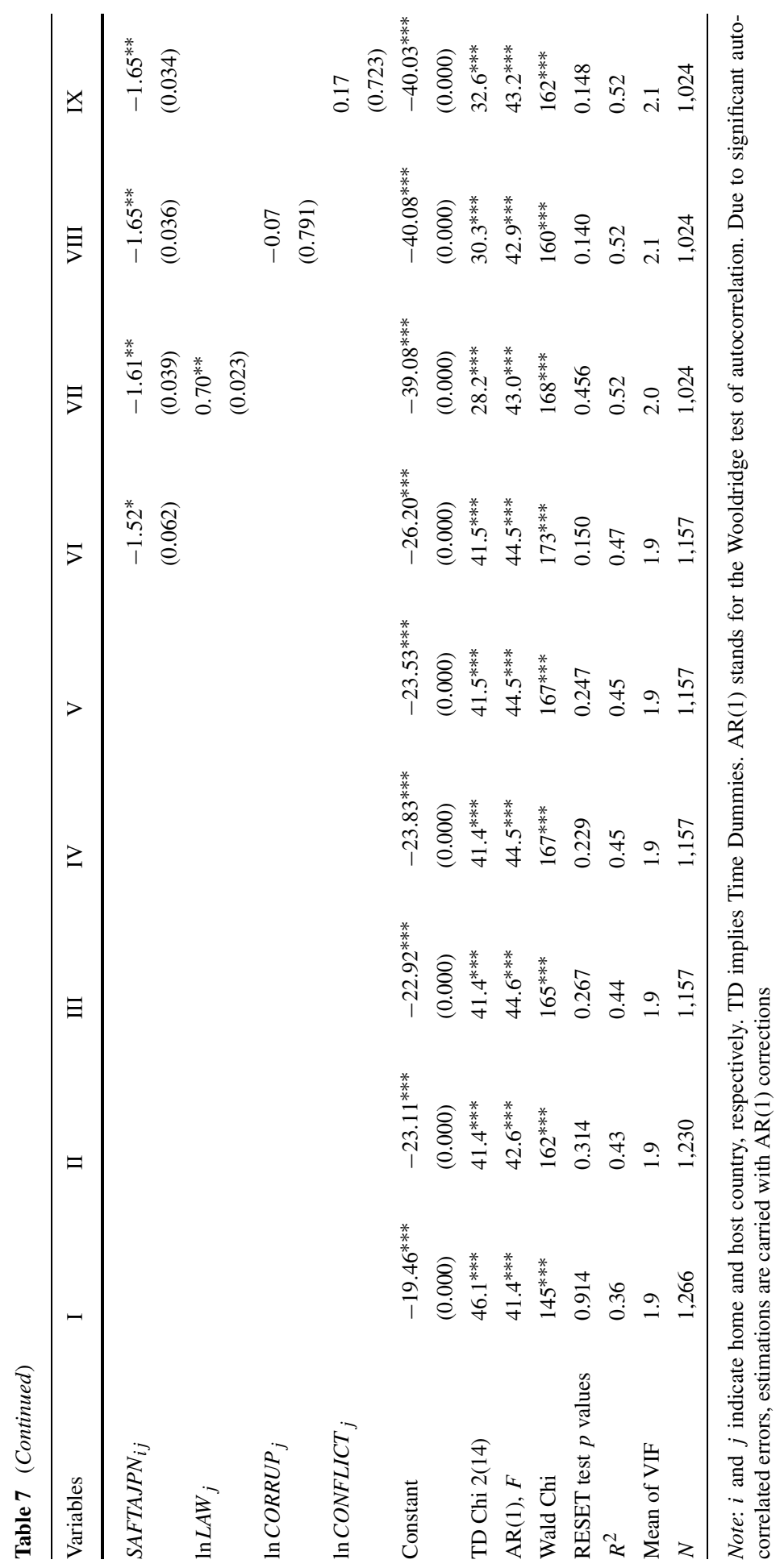


FDI projects in Asian developing countries is not significantly impacted by the host country's index of internal conflict.

\section{Conclusion}

Developing and least developed members of ASEAN and SAFTA have implemented far-reaching initiatives to liberalize FDI policies, and they are still advancing toward a more competitive opening to trigger economic growth through technology transfer, employment generation, and productivity boosts. Over time, they have designed closely matched policy environments and fiscal incentives to attract foreign investors. However, the performance in FDI attraction is quite uneven and also disappointing for some countries. We, therefore, attempted to empirically examine the role of liberalization on capital inflow. The main focus of the study was to unveil the effect of BIT, BTA, and RTA on FDI. This study also discerns Japan's role as a source of FDI in ASEAN and SAFTA countries, which, in turn, discloses the degree of integration between the source and recipients of FDI. Furthermore, we assess the criticality of some factors pertaining to the institutional strengths of the host countries.

In this paper, the econometric results provide evidence that neither BITs nor BTAs constitute a strategic instrument for inducing foreign investment in the developing countries in Asia. Such estimates bring to light the fact that extensive engagement in bilateral agreements has less opportunity to foster the inflow of foreign capital if liberal FDI policies already exist in the host countries and they compete for vertical investment. Because the developing countries in Asia have long been practicing competitive liberalization of FDI regulations, there is less room for them to design convincing and customized incentives under BITs and BTAs. Therefore, some of the sample host countries have failed to stimulate their performance in hosting foreign investment, although they have signed a substantial number of investment agreements over time and even with dominant homes of FDI. For instance, an investment agreement between Japan and Bangladesh went into force in August 1999 and between Japan and Pakistan in May 2002. In spite of a long period of existence of those BITs, Bangladesh and Pakistan host a very negligible portion of their annual FDI from Japan. On the contrary, Thailand received a healthy part of its total annual foreign investment from Japan, although they implemented a bilateral free trade agreement only in November 2007. ${ }^{14}$ Above all, SAFTA countries exhibit a significantly lower degree of integration with Japan via FDI, although bilateral investment agreements are prevalent, except between India and Japan. ${ }^{15}$ In this circumstance, countries in South Asia may explore other possible avenues for increasing economic and cultural cooperation with Japan. Like in ASEAN countries, intensifying the extent of integra-

\footnotetext{
${ }^{14}$ Milner et al. (2004) provide evidence that FDI from Japan to Thailand generally takes the vertically integrated nature, in which case Japanese investors locate part of the production process in Thailand and export back home. In this case, the motive for Japanese investment is to avoid higher labors costs at home. The authors further argue that Japanese firms seek to utilize the advantage of the US preferential trade policy toward Thailand and fiscal incentives granted by the Thai government.

${ }^{15}$ India and Japan signed a bilateral FTA that came into force in August 2011.
} 
tion and cooperation within the SAFTA region might also contribute to improving FDI performance of South Asian countries.

Our findings suggest that a host country's economic growth, development of human capital, improvement of infrastructure, and better law and order situation positively affect firms' investment decisions. Therefore, developing countries need to prioritize their funding in the fields of education, training, transport, communication systems, and institutional capacity building in order to strengthen their attractiveness as potential hosts of FDI. Owing to the negative effect of distance and the positive outcome of ASEAN integration on inward FDI, intra-ASEAN investment is likely to increase in the future. Furthermore, ASEAN and SAFTA countries possess comparable comparative advantages and compete for labor-intensive FDI by granting similar kinds of incentives and treatments. Under this circumstance, the inability to institute desirable states of legal and regulatory environments act as a major stumbling block to FDI growth.

\section{Competing Interests}

The authors declare that they have neither any financial nor any non-financial competing interests. No organization has financed this manuscript and no organization will gain anything from the publication of this paper. The authors neither hold any patents nor currently apply for any patents relating to the contents of the manuscript.

\section{Authors' Contributions}

The main idea of the paper was proposed by KI and MSU designed the manuscript initially. Both the authors contributed to the collection and analysis of data and performed all the steps of the proofs in this research. Both the authors also read and approved the final manuscript.

Acknowledgements The authors are thankful to the two anonymous referees for their judicial comments and suggestions. Earlier versions of this paper were presented at the 2013 Spring Conference of the Japanese Economics Association; the 2013 Spring Conference of the Japan Association for Applied Economics; 2013 Asia Pacific Conference: Revitalization and Development, Asia Pacific University, Beppu, Japan; and the Advances in Business-Related Scientific Research Conference, Venice, Italy, 2013. The authors express thanks and gratitude to the discussants and participants of conferences for their insightful comments and suggestions.

\section{Appendix: Variable Explanation and Data Sources}

- $F D I_{i j t}$ : Annual inflow of FDI from country $i$ to country $j$ at year $t$ came from the UNCTAD World Investment Report.

- $G D P_{i t}\left(G D P_{j t}\right)$ : Real GDP of home (host) country at year $t$ were taken from the World Bank's World Development Indicators (WDI). Missing data were collected from the UN statistical database. Nominal GDP was converted to real GDP by using the GDP deflator $(2005=100)$.

- $G D P P C_{i t}\left(G D P P C_{j t}\right)$ : Real GDP per capita of home (host) country at year $t$ were obtained from the World Bank's World Development Indicators (WDI).

- $D I S T_{i j}$ : Geographic distance between capital cities of country $i$ and $j$ was taken from the CEPII's distance database. 
- $O P E N_{j t}$ : Openness of country $j$ at year $t$. It measures total trade (export + import) as a percentage of GDP. Export and import data were supplied by the IMF's Direction of Trade Statistics (DOT) CD-ROM.

- $H D_{j t}$ : Human development of the host country is proxied by gross secondary school enrollment rate, and the data came from the WDI database.

- $R A I L P C_{j t}$ : Rail line per 100,000 people of country $j$ at year $t$. Total length of rail line network of each host country was generated from various sources, including the World Development Indicators (WDI), the ASEAN Statistical Year Book, and the country-specific government database on transport and communication.

- $B T A_{i j t}$ : Bilateral trade agreements between countries $i$ and $j$ at year $t$. The WTO list of trade agreements provided the data.

- $B I T_{i j t}$ : Bilateral investment treaties between countries $i$ and $j$ at year $t$ until the June 2012 were obtained from UNCTAD's country-specific lists of bilateral investment treaties.

- $A S E A N_{i j t}$ : It takes the value 1 if countries $i$ and $j$ belong to the ASEAN at time $t$; otherwise, it is zero. This variable measures intra-ASEAN investment flows, and the expected sign is positive.

- $A S E A N J P N_{i j t}$ : Dummy variable that takes the value 1 if the host country belongs to ASEAN and the source country is Japan. This variable intends to reveal the extent of integration between Japan and the ASEAN countries via FDI.

- SAFTAJPN $N_{i j t}$ : Dummy variable that takes the value 1 if the host country belongs to SAFTA and the source country is Japan. This variable measures the extent of integration between Japan and the SAFTA countries via FDI.

- $L A W_{j t}$ : Index of law and order of country $j$ at year $t$ was provided by the International Country Risk Guide (ICRG). The "law" element measures the strength and impartiality of the legal system, while the "order" element is an assessment of popular observance of the law. Altogether, the value of this index ranges from 0 to 6 points. A higher score indicates better law and order and is expected to induce FDI positively. Thus, the index of law and order is expected to show a positive sign.

- CORRUP ${ }_{j t}$ : Index of corruption of country $j$ at year $t$, which comes from the International Country Risk Guide (ICRG). The total value of the index ranges from 0 to 6 . The lower the score, the lower the risk and vice versa. Thus, the index of corruption is likely to show a negative sign.

- CONFLICT $T_{j t}$ : Index of internal conflict of country $j$ at year $t$ was also taken from the International Country Risk Guide (ICRG). This is an assessment of political violence in the country and its actual or potential impact on governance. The score of this index ranges from 0 to 12 and is summed up from three subcomponents: (a) civil war/coup threat; (b) terrorism/political violence; and (c) civil disorder. A higher score represents a lower intensity of internal conflict, while a lower score indicates a higher intensity of conflict. The expected FDI effect of internal conflict index is positive.

\section{References}

Anderson JE (1979) A theoretical foundation for the gravity equation. Am Econ Rev 69(1):106-116 Anderson JE (2011) The gravity model. Annu Rev Econ 3(1):133-160 
Asian Development Bank (2007) South Asia economic report: foreign direct investment in South Asia. Manila, Philippines

Baldwin RE (1994) Towards an integrated Europe. CEPR, London

Baum CF (2006) An introduction to modern econometrics using STATA. STATA Press, College Station

Bellak C, Leibrecht M, Damijan JP (2009) Infrastructure endowment and corporate income taxes as determinants of foreign direct investment in Central and Eastern Europe countries. World Econ 32(2):267290

Bergstrand JH (1985) The gravity equation in international trade: some microeconomic foundations and empirical evidence. Rev Econ Stat 67(3):474-481

Bergstrand JH (1989) The generalized gravity equation, monopolistic competition and the factor proportion theory in international trade. Rev Econ Stat 71(1):143-153

Bevan AA, Estrin S (2004) The determinants of foreign direct investment into European transition economies. J Comp Econ 32(4):775-787

Blonigen BA, Wang M (2004) Inappropriate pooling of wealthy and poor countries in empirical FDI studies. Working paper 10378, NBER, Cambridge

Blonigen BA (2005) A review of the empirical literature on FDI determinants. Atl Econ J 33(4):383-403

Busse M, Groizard JL (2008) Foreign direct investment, regulations, and growth. World Econ 31(7):861886

Busse M, Koeniger J, Nunnenkamp P (2010) FDI promotion through bilateral investment treaties: more than a bit? Rev World Econ 146(1):147-177

Caves RE (1996) Multinational enterprise and economic analysis, 2nd edn. Cambridge University Press, Cambridge

Chakrabarti AB (2001) The determinants of foreign direct investment: sensitivity analyses of cross-country regressions. Kyklos 54(1):89-113

Chantasasawat B, Fung KC, Hitomi I, Alan S (2010) FDI flows to Latin America, East and Southeast Asia, and China: substitutes or complements? Rev Dev Econ 14(3):533-546

Cuyvers L, Soeng R, Plasmans J, Bulcke DVD (2011) Determinants of foreign direct investment in Cambodia. J Asian Econ 22(3):222-234

Deardorff AV (1998) Determinants of bilateral trade: does gravity work in a neoclassical world? In: Frankel JA (ed) The regionalization of the world economy. University of Chicago Press, Chicago, pp 7-32

Dee P, Gali J (2003) The trade and investment effects of preferential trading agreements. Working paper 10160, NBER, Cambridge

Egger P, Pfaffermayr M (2004) The impact of bilateral investment treaties on foreign direct investment. J Comp Econ 32(4):788-804

Egger P, Winner H (2005) Evidence on corruption as an incentive for foreign direct investment. Eur J Polit Econ 21(4):932-952

Eichengreen B, Irwin DA (1995) Trade blocs, currency blocs and reorientation of world trade in the 1930s. J Int Econ 38(1-2):1-24

Evenett SJ, Keller W (2002) On theories explaining the success of the gravity equation. J Polit Econ 110(2):281-316

Feenstra RC, Markusen JA, Rose AK (2001) Using the gravity equation to differentiate among alternative theories of trade. Can J Econ 34(2):430-447

Gast M, Herrmann R (2008) Determinants of foreign direct investment of OECD countries 1991-2001. Int Econ J 22(4):509-524

Hallward-Driemeier M (2003) Do bilateral investment treaties attract FDI? Only a bit ... and they could bite. Policy research working paper 3121, World Bank, Washington

Lee C, Plummer MG (2004) Economic development in China and its implications for East Asia. Working paper, University of Hawaii at Manoa

Lesher M, Miroudot S (2006) Analysis of the economic impact of investment provisions in regional trade agreements. Trade policy working paper 36, OECD, Paris

Markusen JR (2002) Multinational firms and the theory of international trade. MIT Press, Cambridge

Milner C, Reed G, Talerngsri P (2004) Foreign direct investment and vertical integration of production by Japanese multinationals in Thailand. J Comp Econ 32(4):805-821

Mina WM (2012) The institutional reforms debate and FDI flows to the MENA region: the "best" ensemble. World Dev 40(9):1798-1809

Morrissey O, Udomkerdmongkol M (2012) Governance, private investment and foreign investment in developing countries. World Dev 40(3):437-445

Noorbakhsh F, Paloni A, Youssef A (2001) Human capital and FDI inflows to developing countries: new empirical evidence. World Dev 29(9):1593-1610 
OECD (2004) International investment perspectives. Centre for Cooperation with Non-Members, Paris

Plummer MG, Cheong D (2009) FDI effects of ASEAN integration. Rég Dév 29(1):49-67

Ramsey JB (1969) Tests for specification errors in classical linear least squares regression analysis. J R Stat Soc B 31(2):350-371

Reiter SL, Steensma HK (2010) Human development and foreign direct investment in developing countries: the influence of FDI policy and corruption. World Dev 38(12):1678-1691

Rose AK (2004) Do we really know that the WTO increases trade? Am Econ Rev 94(1):98-114

Silva JMCS, Tenreyro S (2006) The log of gravity. Rev Econ Stat 88(4):641-658

Soloaga I, Winters LA (2001) Regionalism in the nineties: what effect on trade? N Am J Econ Finance 12(1): $1-29$

Tinbergen J (1962) Shaping the world economy: suggestions for an international economic policy. Twentieth Century Fund, New York

Ullah MS, Inaba K (2012) Impact of RTA and PTA on Bangladesh's export: application of a gravity model. J Ind Compet Trade 12(4):445-460

UNCTAD (2000) Bilateral investment treaties 1959-1999. United Nations, Geneva

UNCTAD (2005) World investment report 2005: transnational corporations and the internationalization of R\&D. United Nations, Geneva

UNCTAD (2009) The role of international investment agreements in attracting foreign direct investment to developing countries. UNCTAD series on international investment policies for development. United Nations, Geneva

UNCTAD (2010) World investment report 2010: investing in a low-carbon economy. United Nations, Geneva

Vogiatzoglou K (2007) Vertical specialization and new determinants of FDI: evidence from South and East Asia. Glob Econ Rev 36(3):245-266

Wei S-J (2000) How taxing is corruption on international investors? Rev Econ Stat 82(1):1-11

Wooldridge JM (2002) Econometric analysis of cross section and panel data. MIT Press, Cambridge 